\title{
APPLICATION OF INTERMITTENT FEEDING AND FLASH LIGHTING REGIMENS IN BROILER CHICKENS MANAGEMENT
}

\author{
M. F. A. Farghly and M. N. Makled \\ Dept. of Poultry Production, Fac. of Agric., Univ. of Assiut, Assiut (71516), Egypt. \\ Email: farghly20002000@yahoo.com \& makled@yahoo.com
}

(Received 9/4/2015, accepted 30/5/2015)

\section{SUMMARY}

\begin{abstract}
$\mathrm{T}$ wo experiments were conducted to evaluate the effect of intermittent feeding and flash lighting regimens on growth performance, carcass traits, blood parameters and economic efficiency of broiler chickens. In experiment 1 , one hundred and twenty, one-day old Cobb chicks were equally distributed into four groups (each consisted of 3 replicates of 10 birds each). Chicks in the first group (G1) were fed ad libitum (Control, C), while the other three groups were fed according to intermittent feeding regimes consisted of different number of cycles per day, each cycle consisted of feeding period $(\mathrm{F})$ followed by fasting period (S). Chicks of the second group (G2) were fed in 2 cycles per day, each of 6 hrs feeding followed by 6 hrs fasting (6F: 6S); chicks of the third group (G3) were fed in three cycles per day, each of 4 hrs feeding followed by $4 \mathrm{hrs}$ fasting (4F: $4 \mathrm{~S}$ ) and chicks of the fourth group (G4) were fed in six cycles per day, each of 2 hrs feeding followed by 2 hrs fasting (2F: 2S). In experiment 2, one hundred and twenty, oneday old Cobb chicks were equally distributed into four groups (each consisted of 3 replicates of 10 birds each). Chicks in the first group (G1) were exposed to continuous light/day (Control, C), while the other three groups were exposed to intermittent flash lighting regimens as follows: the second group (G2) was exposed to $2 \mathrm{hrs}$ contiuous light $+1 \mathrm{hr}$ dark for 8 cycles per day (2CL: 1D); the third group (G3) was exposed to $2 \mathrm{hrs}$ continuous light $+1 \mathrm{hr}$ flash light for 8 cycles per day (2CL: 1FL) and the fourth group (G4) exposed to $1 \mathrm{hrs}$ continuous light $+2 \mathrm{hrs}$ flash light for 8 cycles per day (1CL: $2 \mathrm{FL}$ ). The results indicated that intermittent feeding and flash lighting significantly $(\mathrm{P} \leq 0.05)$ affected body weight, body weight gain, feed consumption, feed conversion ratio, and consequently economic efficiency. However, it had no significant effect $(\mathrm{P} \geq 0.05)$ on most carcass traits, meat quality, blood parameters, lymphoid organs and conformation lengths except liver and abdominal fat percentages, tenderness and juiciness of meat, plasma lipids value, percentages of spleen and thymus weight. According to the results of present study and economic evaluation, it could be concluded that, it is possible to use the intermittent feeding regimen of $2 \mathrm{~F}: 2 \mathrm{~S}$ for six cycles/day and flash lighting regimen of $2 \mathrm{CL}$ : $1 \mathrm{FL}$ for 8 cycled/day in broiler management to improve growth and economic efficiency as well as to reduce abdominal fat without any adverse effect till marketing age with expected considerable saving in costs of feed and (electricity).
\end{abstract}

Keywords: broilers, intermittent feeding and flash lighting, carcass and blood traits, performance

\section{INTRODUCTION}

In broilers production, rapid growth rates closely related with several physiological, behavioral and immunological problems such as skeletal and metabolic disorders and changes in behaviors coinciding with high cost of feeding, which is the most expensive item. Allowing birds an unlimited supply of feed usually results in consumption exceeds the bird's requirements for maintenance and production and the excess energy is converted into fat (Peter and Gernat 2006), that not only reduces carcass quality but also feed efficiency (Fontana et al., 1993). Moreover, broilers have usually been kept on a continuous or nearly continuous lighting schedule so as to maximize feed intake and growth rate (Campo and Davila, 2002). Several managerial approaches, both lighting and feeding manipulations have been employed in attempts to restrict feed intake in order to reduce cost of feeding, improve feed efficiency, reduce excessive abdominal fat deposition, as well as lowering incidence of metabolic diseases, visual anomalies, skeletal deformities and circulatory problems. One of these feeding procedures involves restriction of feeding period or frequencies and intermittent lighting programs with compensatory growth are the key factors of feed management strategies to decrease the previous problems, which may be related to activity patterns, consequently energy expenditure (Mench, 2002; Nielsen et al., 2003; Oyedeji 
and Atteh, 2005; Tolkamp et al., 2005; Peter and Gernat 2006; Novel et al., 2009; Onbasilar et al., 2009; $\left.\begin{array}{lllllllllllllllllllllllllll}\mathrm{F} & \mathrm{a} & \mathrm{r} & \mathrm{g} & \mathrm{h} & \mathrm{l} & \mathrm{y} & \mathrm{a} & \mathrm{n} & \mathrm{d} & \mathrm{H} & \mathrm{a} & \mathrm{s} & \mathrm{s} & \mathrm{a} & \mathrm{n} & \mathrm{i} & \mathrm{e} & \mathrm{n} & , & 2 & 0 & 1 & 2\end{array}\right)$.

Light is integral to sight, including both visual acuity and allows establishing rhythmicity, as well as synchronizing many essential functions, including body temperature, stimulates secretory patterns of several hormones and various metabolic steps that facilitate feeding and digestion (Olanrewaju et al., 2006). Alternative lighting programs can be classified into intermittent, restricted, combination of intermittent and restricted and light flashes schedules. Under intermittent light, birds eat about $80 \%$ of their total feed intake during the light period and eat little during the dark period (Buyse et al., 1996). Furthermore, there are many potential welfare benefits associated with shorter photoperiods including: increased sleep, lower physiological stress, improved immune responsiveness, bone metabolism and leg strength, reduction in mortality and improvement in feed conversion, consequently, lower production costs. Also, it is assumed that the reduction of activity and resting or sleeping during darkness may result in lower heat production by 25\% and have higher serum melatonin levels (Rahimi, et al., 2005; Abbas et al., 2007). Dust negatively affects the respiratory system of the birds and this is strongly affected by lighting program and the feeding system, it was 4 times higher during light than dark periods (Nielsen et al., 2003; Calvet et al., 2009). Melatonin is secreted during darkness by the pineal gland and sets the internal biological clock that governs different daily and seasonal cycles or rhythms in various physiological systems, including the cardiopulmonary, excretory, antioxidative thermoregulatory, behavioral, immune and neuroendocrine systems (Zeman et al., 2004). Therefore, most of the recent researches have focused on restricting light regimens to improve productivity of broiler chickens.

Recently, there are increasing interest in energy (electricity) saving. Further research, is undoubtedly needed to establish the ultimate optimal feeding and lighting programs for broilers. Intermittent feeding or flashed light for broiler chicks was suggested as an alternative system that can be applied to manipulate continuous or restricted lighting and ad libitum feeding problems (Ahmad et al., 2009; Azis, 2012; Svihusa et al., 2013, Farghly, 2014). Moreover, broilers performance may be affected by the lack of nutrients (amino acids, minerals or vitamins) required for protein synthesis in cell through the feed absence time if the intervals of intermittent feeding or darkening were more than a certain time (Makled et al., 2012). Thus, the present study was conducted on broiler chicks to evaluate the effect of different diurnal length of intermittent feeding and flashed lighting on their growth performance, carcass traits, b 1 o o d p a r a m e t e r s a n d e c o n o m i c e f $\mathrm{f}$ i c i e $n$ c y.

\section{MATERIALS AND METHODS}

\section{Birds and Management:}

Two experiments were conducted at the Research Poultry Farm, Poultry Production Department, Faculty of Agriculture, Assiut University to evaluate the effect of intermittent feeding and flashed lighting system on growth performance, carcass traits, blood parameters and economic efficiency of broiler chickens. In experiment 1 , one hundred and twenty, one-day old Cobb chicks were equally distributed into four groups (each consisted of 3 replicates of 10 birds each). Chicks in the first group (G1) were fed ad libitum (Control, C), while the other three groups were fed according to intermittent feeding regimes consisted of different number of cycles per day, each cycle consisted of feeding period (F) followed by fasting period (S). Chicks of the second group (G2) were fed in 2 cycles per day, each of 6 hrs feeding followed by $6 \mathrm{hrs}$ fasting (6F: 6S); chicks of the third group (G3) were fed in three cycles per day, each of $4 \mathrm{hrs}$ feeding followed by $4 \mathrm{hrs}$ fasting (4F: $4 \mathrm{~S})$ and chicks of the fourth group (G4) were fed in six cycles per day, each of $2 \mathrm{hrs}$ feeding followed by 2 hrs fasting (2F: 2S). In experiment 2, one hundred and twenty, one-day old Cobb chicks were equally distributed into four groups (each consisted of 3 replicates of 10 birds each). Chicks in the first group (G1) were exposed to continuous lighting 24 hrs a day (Control, C), while the other three groups were exposed to intermittent flashed lighting regimens as follows: chicks of the second group (G2) were exposed to 8 cycles per day each of 2 hrs continuous light+1hr dark (2CL: 1D); chicks of the third group (G3) were exposed to 8 cycles per day each of $2 \mathrm{hrs}$ continuous light $+1 \mathrm{hr}$ flashed light (2CL: 1FL) and chicks of the fourth group (G4) were exposed to 8 cycles per day each of $1 \mathrm{hr}$ continuous light $+2 \mathrm{hrs}$ flashed lighting cycles (1CL: 2FL). All sources of natural light were covered with heavy cotton black curtains and blackout plastic curtains which completely prevent any source of natural light. Flash lighting was composed of 20 flashes/ minute provided by flasher apparatus that contained timer and dimmer to justify the flash lighting period and intensity by using incandescent bulbs. Light intensity as measured at the middle of the room ranged 
between 5-10 lux. All birds in the second trial had full-access to feed and drinking water throughout the experimental period (6 weeks). Diets were formulated to contain $23 \% \mathrm{CP}$ and $3000 \mathrm{Kcal}, \mathrm{ME} / \mathrm{Kg}$ as starter from 0 to $3 \mathrm{wks}$ old and $21 \% \mathrm{CP}$ and $3100 \mathrm{Kcal}$. ME/Kg as grower from 3 to $6 \mathrm{wks}$ old.

\section{Measurements and Assessments:}

Live body weight (BW) and feed consumption (FC) were weekly recorded. Average body weight gain (BWG) and feed conversion ratio (FCR, g feed/g gain) were weekly calculated from 0 to 6 weeks of age. At 6 weeks of age, three birds per group were taken as representative samples and slaughtered. The carcass was manually dissected and the following criteria were recorded: weights and percentages (of final body weight) of carcass, dressing (carcass weight + giblets weight), and intestinal tract (after removing their contents). Weights and percentages (of carcass weight) of liver, heart, pancreas, proventriculus, gizzard, abdominal fat, breast, legs (drumstick and thigh), lymphoid organs (spleen, thymus, bursa) and boneless meat were also recorded. Chemical composition of meat samples (mix of breast and legs) was determined according to AOAC procedures (1995). Sensory evaluation was carried out using a panel test by five persons to judge the meat samples for color, texture, tenderness, juiciness, flavour, aroma and acceptability with grades of 10 points. To estimate water holding capacity (WHC), section of muscles was weighed and placed between two filter papers, the papers with meat were placed between two glass plates. The weight losses were evaluated after pressure for 10 minutes by loads of 1.0 $\mathrm{kg}$. Water holding capacity was then expressed as percentage: [( Damp filter papers weight - dry filter papers weight / meat sample weight) $* 100]$. Blood samples were collected at slaughter in heparinized tubes. The blood samples were centrifuged at $3000 \mathrm{rpm}$ for $15 \mathrm{~min}$ and the plasma obtained was stored at $-20{ }^{\circ} \mathrm{C}$ until analysis. Plasma total protein, albumin, total lipids and transaminase enzymes activities (AST and ALT) were determined colorimetrically by diagnostic kits of Spectrum, (Cairo, Egypt). Economic efficiency (EE) and relative economic efficiency (REE) were calculated at the end of the experiment. Some conformation parameters (shank and keal bone lengths and body depth) were measured (cm) and health problems such as leg problems (( foot pad burns, hock discoloration) were recorded. Dead birds were recorded daily and expressed as percentage during the experimental period.

\section{Statistical analysis:}

The data obtained were subjected to statistical analysis by operating randomized complete block design (RCBD) using general linear models (GLM) procedure of SAS Institute (SAS, 1996). Significant differences between treatments means were verified using Duncan's multiple range test (Duncan, 1955). The following model was used for analysis of variance:

$$
\mathrm{Xij}=\mu+\alpha \mathrm{i}+\beta \mathrm{j}+\mathrm{Cij}
$$

Where: Xij = observation $(i=1, \ldots ., I ; j=1, \ldots \ldots, j), \mu=$ overall mean, $\alpha \mathrm{i}=$ replicates $\quad$ effect, $\beta \mathrm{j}=$ treatments effect, $\mathrm{Cij}=$ experimental error.

\section{RESULTS AND DISCUSSSION}

\section{Body weight (BW) and Body weight gain (BWG):}

The results presented in Table (1.a) show that body weight and body weight gain of broiler chicks of $\mathrm{G} 2$ and $\mathrm{G} 4$ tended to decrease at 3 weeks of age $(\mathrm{P} \leq 0.05)$ than the control group. At 6 weeks of age, there were no significant differences in body weight and body weight gain between the treated groups and the control one. It seems that the broiler chicks of the intermittent fed groups were able to compensate the partial depression in body weight occurred till 3 weeks of age due to restricted feeding time. This may be due to gradual physiological adaptation of the birds to the different feeding regimes and probably due to improvement in efficiency of feed conversion. These results indicate that full compensatory growth was attained during the re-feeding period and it seems that the broilers quickly adapted to intermittent feeding. Velleman, et al. (2014) demonstrated that the timing of feed restriction to chicks is critical for the morphological development of the pectoralis major muscle and the expression of genes required for muscle satellite cell proliferation and differentiation. These findings are in agreement with those of Urdaneta-Rincon and Leeson (2002), Demir et al. (2004), Saleh et al. (2005), Tolkamp et al. (2005), Ozkan et al., (2006), Khetani et al., (2008), Onbasilar et al., (2009), Butzen, et al., (2013) and Velleman, et al. (2014). In contrast, Lippens et al. (2000), Petek (2000), Novel et al. (2009), Chris et al. (2011), Hassanein, et al. (2011), Azis (2012) and Svihus et al. (2013) reported that chicks fed ad libitum were heavier than restricted fed groups. 
Results in Table (1.b) show that the intermittent lighting or flash lighting had a significant effect $(\mathrm{P} \leq 0.05)$ on growth performance traits. It was found that body weight of broilers at 3 and 6 wks of age was significantly increased due to intermittent light or flash light (G2: 2CL,1D and G3: 2CL,1FL) compared to continuous light group. While, the intermittent flash lighting (G4: 1CL, 2FL) had intermediate values of body weight. Light treatments showed a significant effect $(\mathrm{P} \leq 0.05)$ on body weight gain at 1-3 and 1-6 wks of age, indicating that chicks exposed to intermittent light or flashes (G2: 2L,2D and G3: 1FL,2CL) exhibited higher body weight gain than those maintained under continuous lighting. The recovery of growth of broilers exposed to intermittent or flash lighting could be attributed to low activity during dark period, better digestion of feed and less maintenance nutrient requirements and having more available energy for growth (Rahimi et al., 2005).. While, birds exposed to continuous light are mostly active that associated with more stress, causing disturbance to their nutrition metabolism and leading to have lower growth performance.

Table (1.a): Growth performance as affected by intermittent feeding (Mean \pm SE).

\begin{tabular}{lccccc}
\hline \multirow{2}{*}{ Traits } & $\begin{array}{c}\text { Age } \\
\text { (day) }\end{array}$ & G1 $(\mathrm{C})$ & $\mathrm{G} 2$ & $\mathrm{G} 3$ & $\mathrm{G} 4$ \\
\cline { 3 - 6 } & 1 & $45.1 \pm 0.2$ & $45.3 \pm 0.3$ & $44.9 \pm 0.3$ & $45.7 \pm 0.3$ \\
Body weight, BW $(\mathrm{g})$ & 21 & $746.2 \pm 7.8^{\mathrm{ab}}$ & $730.5 \pm 6.8^{\mathrm{b}}$ & $754.2 \pm 8.0^{\mathrm{a}}$ & $730.6 \pm 8.3^{\mathrm{b}}$ \\
& 42 & $1913.4 \pm 13.3$ & $1872.7 \pm 21.5$ & $1914.1 \pm 15.6$ & $1900.8 \pm 19.0$ \\
\hline Body weight gain, BWG & $1-21$ & $33.4 \pm 0.4^{\mathrm{ab}}$ & $32.6 \pm 0.3^{\mathrm{b}}$ & $33.8 \pm 0.4^{\mathrm{a}}$ & $32.6 \pm 0.3^{\mathrm{b}}$ \\
(g/bird/day) & $22-42$ & $55.6 \pm 0.9$ & $54.4 \pm 1.0$ & $55.2 \pm 0.8$ & $55.7 \pm 1.0$ \\
\cline { 2 - 6 } & Overall mean & $44.5 \pm 0.3$ & $43.5 \pm 0.5$ & $44.5 \pm 0.4$ & $44.2 \pm 0.5$ \\
\hline Feed consumption, FC & $1-21$ & $63.4 \pm 1.0^{\mathrm{a}}$ & $59.4 \pm 0.8^{\mathrm{ab}}$ & $61.1 \pm 1.2^{\mathrm{ab}}$ & $56.4 \pm 3.1^{\mathrm{b}}$ \\
(g/bird/day) & $22-42$ & $95.6 \pm 2.1$ & $91.1 \pm 1.2$ & $94.7 \pm 1.8$ & $93.2 \pm 2.1$ \\
\cline { 2 - 6 } & & $79.5 \pm 0.9^{\mathrm{a}}$ & $75.2 \pm 0.8^{\mathrm{b}}$ & $76.9 \pm 1.3^{\mathrm{ab}}$ & $74.8 \pm 0.9^{\mathrm{b}}$ \\
\hline Feed conversion ratio, & $1-21$ & $1.90 \pm 0.05^{\mathrm{a}}$ & $1.82 \pm 0.03^{\mathrm{ab}}$ & $1.81 \pm 0.03^{\mathrm{ab}}$ & $1.73 \pm 0.06^{\mathrm{b}}$ \\
FCR (g feed/g gain) & $22-42$ & $1.72 \pm 0.04$ & $1.68 \pm 0.05$ & $1.68 \pm 0.03$ & $1.67 \pm 0.05$ \\
\cline { 2 - 6 } & Overall mean & $1.81 \pm 0.02^{\mathrm{a}}$ & $1.75 \pm 0.02^{\mathrm{ab}}$ & $1.74 \pm 0.03^{\mathrm{ab}}$ & $1.70 \pm 0.04^{\mathrm{b}}$ \\
\hline
\end{tabular}

$a----b$ Means within row followed by different superscripts are significantly different $(P \leq 0.05)$.

Table (1.b): Growth performance as affected by lighting regimens (Mean $\pm \mathrm{SE}$ ).

\begin{tabular}{|c|c|c|c|c|c|}
\hline \multirow{2}{*}{ Traits } & \multirow{2}{*}{$\begin{array}{l}\text { Age } \\
\text { (day) }\end{array}$} & \multicolumn{4}{|c|}{ Groups } \\
\hline & & G1 (C) & G2 & G3 & G4 \\
\hline \multirow{3}{*}{ Body weight, BW (g) } & 1 & $45.4 \pm 0.2$ & $44.9 \pm 0.3$ & $45.7 \pm 0.3$ & $45.2 \pm 0.3$ \\
\hline & 21 & $737.0 \pm 7.8^{\mathrm{b}}$ & $753.3 \pm 8.2^{\mathrm{b}}$ & $780.1 \pm 10.7^{\mathrm{a}}$ & $747.6 \pm 7.1^{\mathrm{b}}$ \\
\hline & 42 & $1920.3 \pm 14.9^{\mathrm{b}}$ & $1978.1 \pm 20.4^{\mathrm{a}}$ & $2004.4 \pm 20.6^{\mathrm{a}}$ & $1965.0 \pm 18.1^{\mathrm{ab}}$ \\
\hline \multirow{2}{*}{$\begin{array}{l}\text { Body weight gain, BWG } \\
\text { (g/bird/day) }\end{array}$} & $1-21$ & $32.9 \pm 0.4^{b}$ & $33.7 \pm 0.4^{\mathrm{b}}$ & $35.0 \pm 0.5^{\mathrm{a}}$ & $33.4 \pm 0.3^{\mathrm{b}}$ \\
\hline & $22-42$ & $56.4 \pm 0.9$ & $58.3 \pm 1.0$ & $58.3 \pm 1.0$ & $58.0 \pm 0.9$ \\
\hline \multicolumn{2}{|c|}{ Overall mean } & $44.6 \pm 0.4^{b}$ & $46.0 \pm 0.5^{\mathrm{a}}$ & $46.6 \pm 0.5^{\mathrm{a}}$ & $45.7 \pm 0.4^{\mathrm{ab}}$ \\
\hline \multirow{2}{*}{$\begin{array}{l}\text { Feed consumption, FC } \\
\text { (g/bird/day) }\end{array}$} & $1-21$ & $63.6 \pm 1.4$ & $59.6 \pm 1.5$ & $61.4 \pm 1.4$ & $58.9 \pm 1.4$ \\
\hline & $22-42$ & $94.9 \pm 1.9^{\mathrm{a}}$ & $92.6 \pm 0.48^{\mathrm{ab}}$ & $90.4 \pm 0.8^{\mathrm{b}}$ & $90.4 \pm 1.3^{\mathrm{b}}$ \\
\hline \multicolumn{2}{|c|}{ Overall mean } & $79.3 \pm 1.0^{\mathrm{a}}$ & $76.1 \pm 0.7^{\mathrm{ab}}$ & $75.9 \pm 0.7^{\mathrm{b}}$ & $74.6 \pm 1.3^{\mathrm{b}}$ \\
\hline \multirow{2}{*}{$\begin{array}{l}\text { Feed conversion ratio, } \\
\text { FCR ( } \mathrm{g} \text { feed/g gain) }\end{array}$} & $1-21$ & $1.93 \pm 0.04^{\mathrm{a}}$ & $1.77 \pm 0.08^{b}$ & $1.76 \pm 0.01^{\mathrm{b}}$ & $1.76 \pm 0.04^{\mathrm{b}}$ \\
\hline & $22-42$ & $1.68 \pm 0.03^{\mathrm{a}}$ & $1.59 \pm 0.02^{\mathrm{ab}}$ & $1.55 \pm 0.02^{\mathrm{b}}$ & $1.56 \pm 0.06^{\mathrm{ab}}$ \\
\hline \multicolumn{2}{|c|}{ Overall mean } & $1.81 \pm 0.01^{\mathrm{a}}$ & $1.68 \pm 0.03^{b}$ & $1.65 \pm 0.01^{\mathrm{b}}$ & $1.66 \pm 0.05^{\mathrm{b}}$ \\
\hline
\end{tabular}

$a----b$ Means within row followed by different superscripts are significantly different $(P \leq 0.05)$.

The replacement of the dark hour with flash lighting may have aided early growth by providing the birds more opportunity to see the feed, reduction of heat production and stimulates secretory patterns of several hormones (Abbas et al., 2007; Farghly, 2014). Hoption (2006) found that the light programs affect the thyroid hormones that regulating basic metabolism, oxygen consumption (uptake), utilization of 
carbohydrates, proteins and fats, and heat production processes and to affect growth development. The effect of hormones on metabolism involves synthesis of other enzymes, which affect intracellular processes of oxidation and protein synthesis. Also, thyroid hormones stimulate intestinal differentiation and maturation as indicated by cellular changes, increases in alkaline phosphatase activity and digestive enzyme activity. Zeman et al. (2004) reported that melatonin, the major pineal hormone, play a major role in the growth and control of several metabolic processes in poultry. The present results are similar to those reported by Classen et al. (2004); Rahimi et al. (2005); Bölükbasi and Emsen, 2006). Downs et al. (2006); Gharib, et al. (2008); Abbas et al. (2008) and Mahmud, et al. (2011), who reported that intermittent light significantly affect body weight. Also, Farghly (2014) found that light flashes system caused a significant $(\mathrm{P} \leq 0.05)$ increase in body weight and weight gain as compared to continuous light. Classen et al. (2004); Lien et al. (2009); Lewis et al. (2009ab); Lewis et al. (2010) and Schwean-Lardner et al. (2013) indicated that early growth rate was significantly reduced by longer periods of darkness, but gain as well as final body weight was not affected by lighting programs. In contrast, Shutze, et al. (1996); Ingram and Hatten (2000) and Tuleun et al. (2010) found that broilers reared under continuous light gained more weight than those exposed to intermittent or restricted light. Hanaa Khalil et al. (2007) indicated that small difference between the lengths of light hours (2-4 hours) has small impact on body weight and body weight gain. Also, Onbaşlar et al. (2007) found that differences in body weight were not significant in different lighting groups.

\section{Feed consumption (FC) and feed conversion (FCR):}

Results in Table (1. a) reveal that feed consumption and feed conversion ratio at 21 days of age and the overall mean after 6 weeks of age were significantly different $(\mathrm{P} \leq 0.05)$ for $\mathrm{G} 4$ and tended to be different for G2 and G3 than the control group. The intermittently fed groups, especially G4, consumed less feed and utilized feed more efficiently. The improvement in feed conversion under the condition of intermittent feeding could be a result of reducing the amount of spilled feed than those fed ad libitum. Camacho et al. (2004) and Zhan et al. (2007) found that birds subjected to feed restriction system ate less feed compared with those fed ad libitum. Saleh et al. (2005), Novel et al. (2009), Chris et al. (2011) and Hassanein, et al. (2011) reported a significant improvement in feed conversion ratio with feed restriction compared with full feeding. However, Petek (2000), El-Fiky et al. (2008) and Ozkan et al. (2010) reported that feed restriction had insignificant effect on feed intake and feed efficiency. Svihus et al. (2013) found that ad libitum fed broiler chickens ate and drank on average twice per hour and spent close to three-quarters of their time resting, and apart from an increased standing and feed searching activity for intermittently fed birds compared to ad libitum fed birds during the last hour before feed was presented, no differences in activity was detected Chicks would consume all the feed they desired within 2 hrs, and empty their crops sufficiently to eat again after $1 \mathrm{hr}$ of darkness.

Table (1. b) shows that there were significant differences $(\mathrm{P} \leq 0.05)$ between light regimens on feed consumption and feed conversion ratio indicating that broilers exposed to intermittent or flashed light schedule utilized the feed as efficient as those exposed to continuous lighting regimen. Feed consumption of intermittent light of both groups 3 and 4 was less than continuous light (G1), while, G2 group had intermediate values. The feed conversion ratio of intermittent light or flashes (groups 2, 3 and 4) was significantly $(\mathrm{P}<0.05)$ better than continuous light $(\mathrm{G} 1)$. Despite the lower feed intake $(80 \%$ of their total feed intake during the light) in broilers exposed to long hours of darkness or intermittent light (Ohtani and Leeson, 2000), their feed gain ratios were still comparable with those of broilers exposed to continuous light per day, presumably, due to lower energy expenditure on physical activity. Duve et al. (2011) indicated that broilers modify their feeding behaviour according to the prevailing light or dark schedule. Chickens can learn to eat in the dark or flashes, but by less amounts. They can also learn to increase feed intake during the light period in anticipation of the dark period, but are limited by their crop size (Buyse et al., 1996). Previous studies obtained similar results reported by Classen, et al. (2004), SchweanLardner et al. (2012) who showed that longer periods of darkness prevent regular access to feed and consequently reduce feed intake.

The obtained results are in agreement with Ohtani and Leeson, (2000), Oyedeji and Atteh (2005), Rahimi et al. (2005); Onbasilar et al. (2007), Lewis et al. (2009ab) and Fargly (2014), who reported that bio-intermittent light or light flashes schemes significantly affect the feed consumption and feed conversion of chickens. Significant improvement in feed conversion have been recorded in broilers reared under intermittent light schedule compared to birds receiving long photoperiod (Classen et al., 2004, Rahimi et al., 2005; Bölükbasi and Emsen, 2006; Gharib, et al., 2008; Onbasilar et al., 2007; Lien et al., 2009; El-Slamoney et al., 2010). The improvement in FCR could be due to lower feed consumed and feed waste as well as, better digestion and low energy expenditure during the dark phases by increased melatonin secretion. In contrast, some investigations have demonstrated that chickens exposed to 
continuous light increased feed consumption than those given period of light and darkness (Shutze, et al., 1996). Mahmud, et al. (2011) and Mustafa and Muneer (2013) showed that the feed consumption by the birds under intermittent light was not significantly different from continuous light regimes but FCR was significantly better than the group exposed to continuous light. Also, Tuleun et al. (2010) and Duve et al. (2011) reported that feed conversion was not significantly different between continuous and limited lighting. Saiful et al. (2002); Oyedeji and Atteh (2005); Downs et al. (2006); Abbas et al. (2008) and ElFiky et al. (2008) found that chicks reared under intermittent light showed no significant differences in feed consumption and feed conversion compared to those under continuous light.

\section{Carcass traits and meat quality:}

Results in Tables (2.a,b and 3.a,b) reveal that intermittent feed did not have significant effect on most of carcass characteristics and meat quality except on drumstick, liver and abdominal fat percentages; meat tenderness, juiciness and ether extract percentage $(\mathrm{P} \leq 0.05)$. This effect was more pronounced in $\mathrm{G} 2$ (6F:6S). These findings partially agree with those reported by Nematallah et al. (2003); Demir et al. (2004); Saleh et al. (2005); Khetani et al. (2008); Onbasilar et al. (2009) and Butzen, et al. (2013), who indicated that restricted feeding did not affect the carcass characteristics and the relative weights of different organs, except that of liver percentage. Velleman, et al. (2014) found that the timing of feed restrictions in chicks is critical in the deposition of fat in the pectoralis major muscle and expression of adipogenic genes. The significantly higher deposition of abdominal fat in the control birds over those of the intermittently fed chickens agrees with the findings of Nielsen et al. (2003), and Zhan et al. (2007). Moreover, Farghly and Hassanien (2012) did not reveal any significant differences in sensory characteristics except juiciness due to feed restrictions. In addition, Zhan et al. (2007) and El-Fiky et al. (2008) found that ether extract content of breast muscle was decreased, whereas protein content was increased by feed restriction. The results of Makled et al. (2012) indicated that the intermittent feeding of methionine and lysine had a significant negative impact on the chemical composition of femur meat (low protein and fat percentages). On the contrary, Lippens et al. (2000) and Camacho et al. (2004) reported no significant difference in abdominal fat due to feed restriction. Besides, Urdaneta-Rincon and Leeson (2002) and Zhan et al. (2007) found that feed restriction reduced breast muscle percentage. Also, Petek, (2000) and El-Fiky et al. (2008) found that broilers subjected to 6-hours feed removal had greater percentages of carcass, liver, heart and gizzard weights than those subjected to 3 - hours feed removal and full-fed.

Table (2. a): Carcass traits and body organs as affected by intermittent feeding (Mean $\pm \mathrm{SE}$ ).

\begin{tabular}{lcccc}
\hline \multirow{2}{*}{ Traits } & \multicolumn{3}{c}{ Groups } \\
\cline { 2 - 4 } & $\mathrm{G} 1(\mathrm{C})$ & $\mathrm{G} 2$ & $\mathrm{G} 3$ & $\mathrm{G} 4$ \\
\hline A: Carcass traits: & & & & \\
\hline Live BW (g) & $1900.8 \pm 12.6$ & $1884.5 \pm 14.2$ & $1910.0 \pm 16.0$ & $1896.8 \pm 10.5$ \\
Dressing, \% & $77.9 \pm 0.7$ & $77.7 \pm 0.8$ & $78.6 \pm 1.1$ & $78.0 \pm 1.0$ \\
Drumstick, \% & $13.0 \pm 0.3^{\mathrm{a}}$ & $11.9 \pm 0.3^{\mathrm{b}}$ & $12.8 \pm 0.3^{\mathrm{ab}}$ & $12.8 \pm 0.3^{\mathrm{ab}}$ \\
Femur, \% & $14.1 \pm 0.6$ & $14.2 \pm 0.6$ & $14.2 \pm 0.4$ & $14.0 \pm 0.3$ \\
Breast, \% & $24.3 \pm 0.5$ & $24.0 \pm 0.5$ & $24.4 \pm 0.4$ & $24.0 \pm 0.6$ \\
Giblets, \% & $5.9 \pm 0.3$ & $6.0 \pm 0.4$ & $5.9 \pm 0.2$ & $5.6 \pm 0.3$ \\
Boneless meat, \% & $82.6 \pm 0.9$ & $82.0 \pm 0.3$ & $83.0 \pm 0.8$ & $82.9 \pm 0.6$ \\
Abdominal fat, \% & $1.8 \pm 0.1^{\mathrm{a}}$ & $1.5 \pm 0.1^{\mathrm{b}}$ & $1.5 \pm 0.1^{\mathrm{b}}$ & $1.7 \pm 0.1^{\mathrm{ab}}$ \\
\hline B: Body organs: & & & & \\
\hline Carcass weight (g) & $1385.3 \pm 12.6$ & $1369.5 \pm 15.8$ & $1404.2 \pm 12.2$ & $1383.5 \pm 9.6$ \\
Liver, \% & $2.91 \pm 0.06^{\mathrm{ab}}$ & $3.13 \pm 0.09^{\mathrm{a}}$ & $2.92 \pm 0.05^{\mathrm{ab}}$ & $2.60 \pm 0.04^{\mathrm{b}}$ \\
Heart, \% & $0.50 \pm 0.02$ & $0.49 \pm 0.02$ & $0.48 \pm 0.01$ & $0.50 \pm 0.02$ \\
Gizzard, \% & $2.51 \pm 0.05$ & $2.40 \pm 0.08$ & $2.53 \pm 0.04$ & $2.49 \pm 0.06$ \\
Pancreas, \% & $0.48 \pm 0.02$ & $0.46 \pm 0.01$ & $0.46 \pm 0.01$ & $0.47 \pm 0.02$ \\
Proventriculus, \% & $0.60 \pm 0.02$ & $0.60 \pm 0.03$ & $0.59 \pm 0.02$ & $0.62 \pm 0.03$ \\
Small intestine, \% & $3.82 \pm 0.19$ & $4.04 \pm 0.26$ & $3.80 \pm 0.18$ & $3.83 \pm 0.29$ \\
Small intestine length, cm & $174.8 \pm 6.0$ & $179.4 \pm 5.9$ & $173.2 \pm 4.8$ & $172.4 \pm 6.2$ \\
\hline
\end{tabular}

$a----b$ Means within row followed by different superscripts are significantly different $(P \leq 0.05)$.

In the current study, no significant difference was found among lighting regimens on all carcass traits and meat quality except abdominal fat, ether extract percentages and juiciness value (Tables, 2.b and 3 b). 
Birds exposed to continues lighting $(\mathrm{G} 1, \mathrm{C})$ had significant highest value of abdominal fat and ether extract percentages compared to other treatments (G2, G3 and G4). However, birds subjected to intermittent or flash lighting (G2 and G3) had significant higher value of juiciness than those of G4. Lawrence and Fowler (1997) reported that thyroid hormones stimulate the basic metabolic rate through regulation of the metabolism of carbohydrates, proteins and lipids. Farghly (2014) found that no significant differences for the percentages of dressed carcass, drumsticks, femurs, breast, heart and gizzard among all groups under light flashes. However, the differences were significant $(\mathrm{P} \leq 0.05)$ for liver, giblets and abdominal fat percentages. Intermittent or flash lighting could be used as a tool for reducing abdominal fat and upgrading carcass quality of broilers. These results were similar to findings of Renden et al. (1996); Downs et al. (2006) and Onbaşılar et al. (2007) who, found that carcass traits and organ weights were not significant in different lighting groups. Chen et al. (2007) and Lewis et al. (2009b) reported that breast meat yield was unaffected by photoperiod in broilers. Also, El-Fiky et al. (2008) found that heart, liver and gizzard percentage were not affected by light regime. Buyse et al. (1996); Ohtani and Leeson (2000); Rahimi et al. (2005) and Oyedeji and Atteh (2005) found that there was significant reduction in abdominal fat of broilers exposed to intermittent light as against the continuous light per day. However, Chen et al. (2007) and El-Fiky et al. (2008) reported that no significant difference was found among light regimes on abdominal fat. El-Fiky et al. (2008) and Lien et al. (2009) found that chicks reared under intermittent light showed significant improvements in carcass characteristics. Intermittent lighting was found to enhance protein content of breast meat in broiler chickens when compared with continues light. This may have occurred because intermittent light promoted the retention of nitrogen (Buyse et al., 1996). Li et al. (2010) found that intermittent lighting schedules produced higher protein content in breast meat.

Table (2. b): Carcass traits and body organs as affected by lighting regimens (Mean $\pm \mathrm{SE})$.

\begin{tabular}{lcccc}
\hline \multirow{2}{*}{ Traits } & \multicolumn{4}{c}{ Groups } \\
\cline { 2 - 4 } & $\mathrm{G} 1(\mathrm{C})$ & $\mathrm{G} 2$ & $\mathrm{G} 3$ & $\mathrm{G} 4$ \\
\hline A: Carcass traits: & $1915.2 \pm 10.4$ & $1905.8 \pm 13.9$ & $1940.0 \pm 12.0$ & $1908.6 \pm 15.8$ \\
\hline Live BW (g) & $78.1 \pm 0.9$ & $79.0 \pm 0.8$ & $78.7 \pm 1.1$ & $77.9 \pm 1.0$ \\
Dressing, \% & $12.9 \pm 0.4$ & $12.8 \pm 0.3$ & $12.9 \pm 0.5$ & $12.7 \pm 0.3$ \\
Drumstick, \% & $14.0 \pm 0.3$ & $14.2 \pm 0.4$ & $14.1 \pm 0.6$ & $13.9 \pm 0.5$ \\
Femur, \% & $23.9 \pm 0.7$ & $24.3 \pm 0.4$ & $24.4 \pm 0.6$ & $24.2 \pm 0.5$ \\
Breast, \% & $5.9 \pm 0.4$ & $5.8 \pm 0.5$ & $6.0 \pm 0.3$ & $5.9 \pm 0.4$ \\
Giblets, \% & $82.8 \pm 0.4$ & $82.9 \pm 0.9$ & $83.0 \pm 0.6$ & $83.7 \pm 0.8$ \\
Boneless meat, \% & $1.7 \pm 0.1^{\mathrm{a}}$ & $1.4 \pm 0.1^{\mathrm{b}}$ & $1.4 \pm 0.1^{\mathrm{b}}$ & $1.4 \pm 0.1^{\mathrm{b}}$ \\
Abdominal fat, \% & \multicolumn{4}{c}{} \\
\hline B: Body organs: & $1382.1 \pm 9.8$ & $1395.1 \pm 14.6$ & $1410.4 \pm 16.3$ & $1374.2 \pm 11.2$ \\
\hline Carcass weight (g) & $2.91 \pm 0.05$ & $2.93 \pm 0.04$ & $3.02 \pm 0.06$ & $2.89 \pm 0.08$ \\
Liver, \% & $0.49 \pm 0.01$ & $0.50 \pm 0.02$ & $0.49 \pm 0.02$ & $0.48 \pm 0.01$ \\
Heart, \% & $2.52 \pm 0.05$ & $2.47 \pm 0.07$ & $2.50 \pm 0.04$ & $2.49 \pm 0.08$ \\
Gizzard, \% & $0.46 \pm 0.02$ & $0.47 \pm 0.01$ & $0.48 \pm 0.02$ & $0.48 \pm 0.01$ \\
Pancreas, \% & $0.61 \pm 0.02$ & $0.58 \pm 0.03$ & $0.59 \pm 0.03$ & $0.59 \pm 0.04$ \\
Proventriculus, \% & $4.02 \pm 0.26$ & $3.94 \pm 0.18$ & $3.92 \pm 0.19$ & $3.89 \pm 0.33$ \\
Small intestine, \% & $180.1 \pm 4.9$ & $176.4 \pm 8.0$ & $177.2 \pm 6.2$ & $175.9 \pm 7.4$ \\
Small intestine length, cm & & &
\end{tabular}

No significant $(\mathrm{P}>0.05)$ differences were detected for all studied blood parameters between the intermittently fed chickens and the control ones (Table 4, a). It is noteworthy to mention that the revealed differences in liver weight and percentage did not have any ampact on AST and ALT activities. These results are similar to those of Nematallah et al. (2003), Demir et al. (2004) and Khetani et al. (2008), who reported that no significant differences were proved for blood parameters due to feed restriction. In contrast, Abdel-Fattah et al. (2003) and El-Fiky et al. (2008) found that feed restriction significantly affected values of total protein, albumin, globulin, total lipids, and cholesterol. Also, Rajman et al. (2006) and Ozkan et al. (2010) found that feed restriction or frequency reduced plasma protein, albumin, lipids and cholesterol. In addition, Moradi et al. (2012) found that multi-meal-fed birds had significantly lower blood glucose, AST, ALT and cholesterol than those fed once a day 
Table (3. a): Meat quality traits as affected by intermittent feeding (Mean $\pm \mathrm{SE}$ ).

\begin{tabular}{|c|c|c|c|c|}
\hline \multirow{2}{*}{ Traits } & \multicolumn{4}{|c|}{ Groups } \\
\hline & G1 (C) & G2 & G3 & G4 \\
\hline \multicolumn{5}{|l|}{ A: Sensory traits: } \\
\hline Aroma & $8.4 \pm 0.4$ & $8.3 \pm 0.3$ & $8.6 \pm 0.6$ & $8.5 \pm 0.5$ \\
\hline Color & $8.4 \pm 0.5$ & $8.4 \pm 0.4$ & $8.2 \pm 0.5$ & $8.3 \pm 0.4$ \\
\hline Flavor & $8.6 \pm 0.6$ & $8.6 \pm 0.4$ & $8.7 \pm 0.5$ & $8.7 \pm 0.4$ \\
\hline Tenderness & $8.3 \pm 0.6^{\mathrm{ab}}$ & $7.7 \pm 0.6^{\mathrm{b}}$ & $8.9 \pm 0.6^{\mathrm{a}}$ & $7.7 \pm 0.3^{\mathrm{b}}$ \\
\hline Juiciness & $8.3 \pm 0.3^{\mathrm{ab}}$ & $7.7 \pm 0.6^{\mathrm{b}}$ & $8.9 \pm 0.6^{\mathrm{a}}$ & $8.3 \pm 0.4^{\mathrm{ab}}$ \\
\hline Acceptability & $8.4 \pm 0.2$ & $8.2 \pm 0.4$ & $8.6 \pm 0.6$ & $8.3 \pm 0.3$ \\
\hline \multicolumn{5}{|l|}{ B: Physical traits: } \\
\hline Texture & $8.5 \pm 0.4$ & $8.3 \pm 0.3$ & $8.9 \pm 0.2$ & $8.8 \pm 0.1$ \\
\hline WHC & $7.1 \pm 1.7$ & $6.7 \pm 1.3$ & $7.0 \pm 1.5$ & $7.0 \pm 1.8$ \\
\hline \multicolumn{5}{|l|}{ C: Chemical traits: } \\
\hline Moisture, $\%$ & $68.0 \pm 1.2$ & $67.7 \pm 1.1$ & $68.1 \pm 0.7$ & $67.9 \pm 1.3$ \\
\hline Protein, $\%$ & $18.2 \pm 0.3$ & $18.2 \pm 0.2$ & $18.2 \pm 0.2$ & $18.1 \pm 0.2$ \\
\hline Ether extract, \% & $12.2 \pm 0.2^{\mathrm{a}}$ & $11.0 \pm 0.3^{\mathrm{b}}$ & $12.0 \pm 0.2^{\mathrm{ab}}$ & $12.1 \pm 0.1^{\mathrm{ab}}$ \\
\hline Ash, \% & $2.1 \pm 0.2$ & $2.1 \pm 0.2$ & $2.1 \pm 0.2$ & $2.2 \pm 0.1$ \\
\hline
\end{tabular}

$a----b$ Means within row followed by different superscripts are significantly different $(P \leq 0.05)$.

Table (3. b): Meat quality traits as affected by lighting regimens (Mean $\pm \mathrm{SE}$ ).

\begin{tabular}{|c|c|c|c|c|}
\hline \multirow{2}{*}{ Traits } & \multicolumn{4}{|c|}{ Groups } \\
\hline & G1 (C) & G2 & G3 & G4 \\
\hline \multicolumn{5}{|l|}{ A: Sensory traits: } \\
\hline Aroma & $8.2 \pm 0.4$ & $8.5 \pm 0.3$ & $8.6 \pm 0.4$ & $8.4 \pm 0.6$ \\
\hline Color & $8.2 \pm 0.4$ & $8.4 \pm 0.4$ & $8.5 \pm 0.5$ & $8.4 \pm 0.5$ \\
\hline Flavor & $8.5 \pm 0.5$ & $8.6 \pm 0.4$ & $8.5 \pm 0.6$ & $8.4 \pm 0.3$ \\
\hline Tenderness & $8.4 \pm 0.6$ & $8.5 \pm 0.5$ & $8.4 \pm 0.5$ & $7.9 \pm 0.7$ \\
\hline Juiciness & $8.3 \pm 0.4^{\mathrm{ab}}$ & $8.8 \pm 0.6^{\mathrm{a}}$ & $8.9 \pm 0.5^{\mathrm{a}}$ & $7.6 \pm 0.2^{b}$ \\
\hline Acceptability & $8.6 \pm 0.5$ & $8.3 \pm 0.6$ & $8.6 \pm 0.4$ & $8.1 \pm 0.4$ \\
\hline \multicolumn{5}{|l|}{ B: Physical traits: } \\
\hline Texture & $8.5 \pm 0.3$ & $8.5 \pm 0.4$ & $8.6 \pm 0.2$ & $8.2 \pm 0.3$ \\
\hline WHC & $7.2 \pm 1.5$ & $7.1 \pm 1.3$ & $7.0 \pm 1.4$ & $6.9 \pm 1.9$ \\
\hline \multicolumn{5}{|l|}{ C: Chemical traits: } \\
\hline Moisture, $\%$ & $68.1 \pm 1.0$ & $68.1 \pm 1.1$ & $67.9 \pm 0.9$ & $67.9 \pm 1.2$ \\
\hline Protein, $\%$ & $18.0 \pm 0.4$ & $18.1 \pm 0.2$ & $18.3 \pm 0.2$ & $18.2 \pm 0.3$ \\
\hline Ether extract, $\%$ & $12.3 \pm 0.1^{\mathrm{a}}$ & $11.3 \pm 0.2^{\mathrm{b}}$ & $11.1 \pm 0.2^{b}$ & $11.0 \pm 0.1^{\mathrm{b}}$ \\
\hline Ash, $\%$ & $2.1 \pm 0.2$ & $2.0 \pm 0.2$ & $2.0 \pm 0.1$ & $2.0 \pm 0.3$ \\
\hline
\end{tabular}

$a----b$ Means within row followed by different superscripts are significantly different $(P \leq 0.05)$.

\section{Blood Parameters:}

Blood profiling, used to detect disorders due to incorrect lighting on metabolic, nutritional and welfare conditions of broilers. In the present study, there was no change in plasma parameters except total lipids values under light programs as results in Table $(4, \mathrm{~b})$ indice that total lipids was significantly decreased due to application of intermittent or flash lighting regimen (G2 and G3) compared to continuous regimen. Plasma total protein, total lipids, cholesterol, AST and ALT were not affected by lighting periods. This result could be due to both direct and indirect effects of melatonin on leptin hormone concentration. These results were in full agreement with those obtained by Onbasilar et al. (2007). Soliman et al. (2006) and Onbasilar et al. (2007) and El-Slamoney et al. (2010) who found that plasma total protein, total lipids, glucose, cholesterol and triglyceride levels did not differ significant among different lighting groups. El-Badry et al. (2009) revealed no significant differences in plasma total protein, globulin among 
light regimes groups, whereas, there was a significant decrease in plasma total protein. This may be attributed to the effect of light regimes on thyroid glands activity. Farghly (2014) found that no significant differences were observed for all blood parameters of flash lighting treated chickens and those of the control, except that of the total lipids, AST and H/L ratio. He found that total lipids were significantly lower in birds reared under light flashes programs for $9 \mathrm{hrs}$ or $12 \mathrm{hrs}$ as compared to the other groups.

Table (4. a): Blood parameters as affected by intermittent feeding (Mean \pm SE).

\begin{tabular}{lcccc}
\hline \multirow{2}{*}{ Traits } & \multicolumn{4}{c}{ Groups } \\
\cline { 2 - 5 } & G1 $(\mathrm{C})$ & $\mathrm{G} 2$ & $\mathrm{G} 3$ & $\mathrm{G} 4$ \\
\hline Total proteins $(\mathrm{g} / \mathrm{dl})$ & $4.02 \pm 0.02$ & $3.96 \pm 0.04$ & $4.00 \pm 0.01$ & $3.92 \pm 0.03$ \\
Albumin $(\mathrm{g} / \mathrm{dl})$ & $2.46 \pm 0.03$ & $2.39 \pm 0.02$ & $2.46 \pm 0.04$ & $2.44 \pm 0.06$ \\
Globulin $(\mathrm{g} / \mathrm{dl})$ & $1.56 \pm 0.06$ & $1.56 \pm 0.08$ & $1.54 \pm 0.09$ & $1.57 \pm 0.09$ \\
Albumin: globulin ratio & $1.58 \pm 0.11$ & $1.53 \pm 0.06$ & $1.60 \pm 0.04$ & $1.55 \pm 0.09$ \\
Total lipids (g/dl) & $13.40 \pm 0.32$ & $12.90 \pm 0.44$ & $12.92 \pm 0.25$ & $13.32 \pm 0.36$ \\
AST (U/L) & $11.00 \pm 0.84$ & $10.74 \pm 0.62$ & $10.88 \pm 0.56$ & $10.94 \pm 0.48$ \\
ALT (U/L) & $3.12 \pm 0.12$ & $2.89 \pm 0.15$ & $2.98 \pm 0.12$ & $3.12 \pm 0.10$ \\
\hline
\end{tabular}

No significant differences were observed $(P>0.05)$.

Table (4. b): Blood parameters as affected by lighting regimens (Mean $\pm \mathrm{SE}$ ).

\begin{tabular}{lcccc}
\hline \multirow{2}{*}{ Traits } & \multicolumn{4}{c}{ Groups } \\
\cline { 2 - 5 } & $\mathrm{G} 1(\mathrm{C})$ & $\mathrm{G} 2$ & $\mathrm{G} 3$ & $\mathrm{G} 4$ \\
\hline Total proteins $(\mathrm{g} / \mathrm{dl})$ & $4.12 \pm 0.02$ & $3.99 \pm 0.03$ & $4.00 \pm 0.02$ & $3.99 \pm 0.04$ \\
Albumin $(\mathrm{g} / \mathrm{dl})$ & $2.57 \pm 0.03$ & $2.47 \pm 0.04$ & $2.49 \pm 0.06$ & $2.50 \pm 0.05$ \\
Globulin (g/dl) & $1.55 \pm 0.08$ & $1.52 \pm 0.07$ & $1.51 \pm 0.08$ & $1.49 \pm 0.09$ \\
Albumin: globulin ratio & $1.66 \pm 0.09$ & $1.63 \pm 0.06$ & $1.65 \pm 0.08$ & $1.68 \pm 0.13$ \\
Total lipids (g/dl) & $15.12 \pm 0.29^{\mathrm{a}}$ & $12.11 \pm 0.39^{\mathrm{b}}$ & $12.10 \pm 0.55^{\mathrm{b}}$ & $13.44 \pm 0.28^{\mathrm{ab}}$ \\
AST (U/L) & $11.00 \pm 0.78$ & $10.85 \pm 0.65$ & $10.92 \pm 0.65$ & $11.00 \pm 0.52$ \\
ALT (U/L) & $3.06 \pm 0.12$ & $2.92 \pm 0.11$ & $2.96 \pm 0.14$ & $3.12 \pm 0.20$ \\
\hline
\end{tabular}

$a----b$ Means within row followed by different superscripts are significantly different $(P \leq 0.05)$.

\section{Conformations and health problems:}

From data of Table $(5, a)$, it could be noticed that intermittent feeding significantly $(\mathrm{P} \leq 0.05)$ affected spleen percentage, while there were no significant differences $(\mathrm{P}>0.05)$ for conformations measurements, thymus or bursa percentages. The mortality rate and leg problems for C, G1, G2 and G4 were 6.66, 3.33, 0.00 and 3.33; and 10.00, 10.00, 3.33, 6.66, respectively. Early-life fast growth rate is accompanied by a number of problems, high incidence of metabolic disorders, high mortality and high incidence of skeletal diseases (Weeks et al., 2000). They may suffer from respiratory diseases, spleen disease and sudden death syndrome (Demir et al., 2004). Feed restricted birds showed an improvement in immune responses, disease resistance and lowering in metabolic or skeletal problems or mortality rate as compared to fully fed birds (Mench, 2002; Ozkan, et al., 2010). In the present study, intermittent feeding had no effect on mortality of the broiler chicks. In accordance with that trend Oyedeji and Atteh (2005), Moreover, ElFiky et al. (2008), Hassanein, et al. (2011) and Farghly and Hassanien (2012) showed that mortality rate was not significantly affected by feed restriction or frequencies. However, Gonzales et al., (1998); Urdaneta-Rincon and Leeson (2002); Abdel-Fattah et al. (2003); Saleh et al. (2005) and O"zkan et al. (2006) reported that early feed restriction significantly lowered (mortality rate of broiler chicks, because early age feed restriction may improve resistance to viral infections.

Sleep deprivation by continuous lighting can have negative impact behavior and health responses. Table $(5, b)$ showed the impact of different lighting regimens on conformations and health problems of broiler chicks. No significant differences were found in conformations and lymphoid organs between different lighting regimens except percentage of thymus. Also, no remarkable differences were found among the experimental groups in leg problems score. Mustafa and Muneer (2013) indicated that increase in the period of darkness adversely effected the mean lymphoid organs (spleen, bursa and thymus weight) and chicks reared on $24 \mathrm{hr}$ light had higher mean thymus weight. Regarding the mortality rate, the results show differences among the experimental groups (10.0, 10.0, 3.33 and 6.66 for G1, G2, G3 and G4, 
respectively). The intermittent lighting program, perhaps, improved the immune performance by enhancing both humoral and cell-mediated response, which was a key factor in reducing mortality rate. In the previous researches, intermittent lighting programs have shown increased livability and decreased metabolic diseases such as ascites, sudden death syndrome, tibial dyschondroplasia and other skeletal disorders and improved immune system (Brickett et al., 2007; Onbasilar et al., 2007; Onbasilar et al., 2007; Lewis et al., 2010). Schwean-Lardner et al. (2013) reported that total mortality, due to metabolic and skeletal disease decreased linearly with increasing inclusion of darkness periods. Evidence of the impact of lighting program on infectious disease was also suggested by positive effects of darkness and melatonin on immune function (Abbas et al., 2008; Schwean-Lardner et al., 2012). Another potential benefit of darkness is the change in bird metabolism that occurs during the dark period and the consequential rejuvenation of tissue (Brickett et al., 2007). Abbas et al. (2008) observed that intermittent light regimen reduced mortality rate by 3 times compared to continuous light regimen. On the contrary, no significant differences between light treatments in mortality was reported by Rahimi, et al. (2005); Gharib, et al. (2008); Lewis et al. (2009b) and Farghly (2014).

Table (5.a): Conformations and health problems of broilers as affected by intermittent feeding (Means \pm SE).

\begin{tabular}{|c|c|c|c|c|c|}
\hline \multirow{2}{*}{ Traits } & & \multicolumn{4}{|c|}{ Groups } \\
\hline & & G1 (C) & G2 & G3 & G4 \\
\hline \multirow{3}{*}{$\begin{array}{l}\text { Lymphoid organs } \\
\qquad(\%)\end{array}$} & Spleen & $0.20 \pm 0.04^{\mathrm{ab}}$ & $0.21 \pm 0.03^{\mathrm{ab}}$ & $0.25 \pm 0.02^{\mathrm{a}}$ & $0.17 \pm 0.03^{b}$ \\
\hline & Thymus & $0.38 \pm 0.02$ & $0.42 \pm 0.01$ & $0.39 \pm 0.03$ & $0.36 \pm 0.02$ \\
\hline & Bursa & $0.16 \pm 0.01$ & $0.19 \pm 0.03$ & $0.18 \pm 0.02$ & $0.16 \pm 0.02$ \\
\hline \multirow{3}{*}{$\begin{array}{l}\text { Conformations } \\
\text { (cm) }\end{array}$} & Shank length & $5.5 \pm 0.14$ & $5.4 \pm 0.15$ & $5.4 \pm 0.18$ & $5.6 \pm 0.14$ \\
\hline & Keal bone length & $5.8 \pm 0.28$ & $5.6 \pm 0.33$ & $5.6 \pm 0.19$ & $5.8 \pm 0.22$ \\
\hline & Body depth & $12.00 \pm 1.00$ & $11.82 \pm 0.60$ & $11.88 \pm 0.48$ & $11.96 \pm 0.66$ \\
\hline \multirow[b]{2}{*}{ Leg problems score } & Foot pad burns & 2.36 & 2.04 & 1.98 & 2.24 \\
\hline & $\begin{array}{l}\text { Hock } \\
\text { discoloration }\end{array}$ & 2.93 & 2.70 & 2.58 & 2.90 \\
\hline Mortality rate, $\%$ & & 10.00 & 10.00 & 3.33 & 6.66 \\
\hline
\end{tabular}

It has been demonstrated that including darkness to a lighting program can improve walking ability and physical activity, which affects energy expenditure and stimulate bone development in broilers (Sanotra et al., 2002; Saiful et al., 2002; Olanrewaju et al., 2006). Increased exercise that is associated with darkness addition may also positively influence skeletal health (Schwean-Lardner et al., 2012). However, it is presumably that increasing darkness increases foot pad lesions, because of increased contact of the foot pad with litter during the scotophase. Tuleun et al. (2010) found that continuous lighting reduced the severity of leg abnormality. Similar findings were reported by Farghly (2014) who indicated that the flash lighting did not affect the severity of the leg problems. Sanotra et al. (2002) concluded that the lighting program not only reduced leg problems but also reduced chronic fear in the birds. Hester et al. (2011) reported that birds exposed to the short lighting photoperiod had longer bones and more bone area because of a delay in bone growth plate closure, However, this delay in bones growth, did not improve bone mineralization. Hanaa Khalil et al. (2007) and Farghly (2014) demonstrated that there were no significant differences between light regimens with respect to bone measures (keel and shank lengths). On the contrary, some findings reported that lighting programs can reduce the incidence of leg disorders in broilers (Renden et al., 1996, Lewis et al., 2009a and Schwean-Lardner et al., 2012 and 2013). Also, Ingram and Hatten (2000) reported that the photoperiod had significant effect on keel length and width as good indicators of skeletal development.

\section{Economic efficiency:}

Any feeding and light strategy that better control of energy intake and would improve feed conversion, minimize feed cost and avoid fatty carcass is usually more likely. The live body weight and feeding cost are generally considered the most important factors involved in achievement of maximum efficiency values. The results presented in Tables (6. a and 6.b) reveal that the relative economic efficiency was better with the intermittently fed group, especially G4 (2F:2S), than with the ad libitum fed group. These results are in agreement with those recorded by Abdel-Fattah et al., (2003) and Novel et al., 
(2009) who stated that economical performance with feed restriction was better than that with full feeding as a result of improvements in viability and feed conversion. The economic aspect of different lighting programs also reveal that the performance of broiler chicks at using the intermittent flash lighting program (2CL: 1FL) in management of chicks improved the economic efficiency and relative economic efficiency of chicks compared with G1, G2 and G4. The results showed that an intermittent flash lighting schedule was more beneficial to broiler production by saving electricity. The first intermittent flash lighting program (G3) fulfills these profit and potentials. Therefore, based on the present study it may be the recommended lighting regimen In agreement with the present results, Rahimi et al. (2005), Onbasilar et al. (2007), El-Slamoney et al. (2010) and Farghly (2014) found that intermittent light or flash lighting improved economic returns for broiler chicks as well as a considerable saving in lighting (electricity) expense.

Table (5. b): Conformations and health problems of broilers as affected by lighting regimens (Means \pm SE).

\begin{tabular}{lllllc}
\hline \multirow{2}{*}{ Traits } & & \multicolumn{4}{c}{ Groups } \\
\cline { 3 - 6 } & & G1(C) & G2 & G3 & G4 \\
\hline \multirow{2}{*}{$\begin{array}{c}\text { Lymphoid organs } \\
(\%)\end{array}$} & Spleen & $0.21 \pm 0.05$ & $0.19 \pm 0.03$ & $0.23 \pm 0.04$ & $0.22 \pm 0.02$ \\
& Thymus & $0.35 \pm 0.03^{\mathrm{b}}$ & $0.39 \pm 0.01^{\mathrm{ab}}$ & $0.43 \pm 0.02^{\mathrm{a}}$ & $0.44 \pm 0.04^{\mathrm{a}}$ \\
& Bursa & $0.17 \pm 0.02$ & $0.19 \pm 0.01$ & $0.18 \pm 0.02$ & $0.19 \pm 0.03$ \\
\hline \multirow{2}{*}{$\begin{array}{l}\text { Conformations } \\
(\mathrm{cm})\end{array}$} & Shank length & $5.4 \pm 0.12$ & $5.5 \pm 0.17$ & $5.6 \pm 0.18$ & $5.5 \pm 0.14$ \\
& Keal bone length & $5.8 \pm 0.19$ & $5.8 \pm 0.28$ & $5.7 \pm 0.22$ & $5.9 \pm 0.30$ \\
\multirow{2}{*}{ Leg problems score } & Body depth & $12.00 \pm 0.82$ & $11.88 \pm 0.76$ & $11.94 \pm 0.55$ & $12.00 \pm 0.60$ \\
\hline & Foot pad burns & 2.36 & 2.58 & 1.98 & 2.04 \\
\hline Mortality rate, \% & discoloration & 2.90 & 2.58 & 2.36 & 2.70 \\
\hline
\end{tabular}

$a----b$ Means within row followed by different superscripts are significantly different $(P \leq 0.05)$.

Table (6.a): Economic efficiency as affected by intermittent feeding.

\begin{tabular}{|c|c|c|c|c|}
\hline \multirow{2}{*}{ Item } & \multicolumn{4}{|c|}{ Groups } \\
\hline & G1 (C) & G2 & G3 & G4 \\
\hline Total costs $(\text { feed costs }+ \text { chick price) })^{1}$, L.E & 19.69 & 18.90 & 19.21 & 18.82 \\
\hline Total revenue; selling price of $\mathrm{BW}^{2}$ (bird /L.E) & 26.84 & 26.17 & 27.08 & 26.69 \\
\hline Net revenue/ bird/L.E (without constant costs $=25 \%$ ) & 7.15 & 7.27 & 7.87 & 7.87 \\
\hline Economic efficiency (EE) & 0.36 & 0.38 & 0.41 & 0.42 \\
\hline Relative economic efficiency (REE) & 100 & 106 & 114 & 117 \\
\hline
\end{tabular}

${ }^{1}$ Price of $1 \mathrm{~kg}$ of ration $=4.40 \mathrm{L.E}{ }^{2}$ Cost of $1 \mathrm{~kg}$ of dressed carcass $=18.00 \mathrm{LE}$

Table (6. b): Economic efficiency as affected by lighting regimens

\begin{tabular}{|c|c|c|c|c|}
\hline \multirow{2}{*}{ Item } & \multicolumn{4}{|c|}{ Groups } \\
\hline & G1 (C) & G2 & G3 & G4 \\
\hline Total costs $(\text { feed costs }+ \text { chick price })^{1}$, L.E & 19.65 & 19.06 & 19.03 & 18.80 \\
\hline Total revenue; selling price of $\mathrm{BW}^{2}$ (bird /L.E) & 26.93 & 27.67 & 28.36 & 27.59 \\
\hline Net revenue/ bird/L.E (without constant costs $=25 \%$ ) & 7.27 & 8.60 & 9.33 & 8.80 \\
\hline Economic efficiency (EE) & 0.37 & 0.45 & 0.49 & 0.47 \\
\hline Relative economic efficiency (REE) & 100 & 1.22 & 1.33 & 1.27 \\
\hline
\end{tabular}

${ }^{1}$ Price of $1 \mathrm{~kg}$ of ration $=4.40 \mathrm{L.E}{ }^{2}$ Cost of $1 \mathrm{~kg}$ of dressed carcass $=18.00 \mathrm{LE}$ 


\section{Farghly and Makled}

\section{CONCLUSION}

The results of this study suggest that intermittent feeding regimen following six cycles per day (2F:2S) and intermittent flash lighting program (2CL: 1FL) decreased feed consumption, improved feed efficiency and increased economic efficiency without any adverse effects on studied performance or physiological parameters till marketing age of broiler chickens with expected considerable saving in feed and energy (electricity) expenses. These recommended regimen (2F:2S) and (2CL: 1FL) seems to be more suitable for broiler strains selected for rapid growth that cannot stand intermittent nutrients supply for more than two hours. Also, such a regimen may be more practicable and acceptable in broilers farms that equipped with automatic feeding and lighting system.

\section{REFERENCES}

Abbas, A.O.; A.K. Alm El-Dein; A.A. Desoky and M.A.A. Galal (2008). The effects of photoperiod programs on broiler chicken performance and immune response. Inter. J. of Poult. Sci., 7: 665-671.

Abbas, A.O.; E. Ahmed Gehad; L. Gilbert Hendricks; H.B.A. Gharib and M.M. Mashaly (2007). The Effect of lighting program and melatonin on the alleviation of the negative impact of heat stress on the immune response in broiler chickens. Inter. J. of Poult. Sci., 9: 651-660.

Abdel-fattah, S.A.; Y.M. El-hommosany and F. M. A. Maie (2003). Response of quail chicks to different quantitative feed restriction regimens: productive, immunological and physiological aspects. Egypt. Poult. Sci., 23:421-440.

Ahmad, F.; A. El-hag; M. Ashraf; M.Z. Siddiqui and H.M. Ishaq (2009). Effect of different intermittent feeding regimes on the performance of broilers. Pakistan J. of Life and Social Sci., 7:131-135.

AOAC (1995). Official Methods of Analysis. 15th ed. Association of Official Analytical Chemists, Arlington, VA.

Azis, A. (2012). Performance and heterophil to lymphocyte (H/L) ratio profile of broiler chickens subjected to feeding time restriction. Inter. J. of Poult. Sci., 11:153-157.

Bölükbasi, S.C. and H. Emsen (2006). The Effect of diet with low protein and intermittent lighting on ascites induced by cold temperatures and growth performance in broilers. Inter. J. of Poult. Sci., 5: 988-991.

Brickett, K.E.; J.P. Dahiya; H.L. Classen; C.B. Annett and S. Gomis (2007). The impact of nutrient density, feed form, and photoperiod on the walking ability and skeletal quality of broiler chickens. Poult. Sci., 86:2117-2125.

Butzen, F.M.; A.M.L. Ribeiro; M.M. Vieira; A.M. Kessler; J.C. Dadalt and M.P. Della (2013). Early feed restriction in broilers. I. Performance, body fraction weights, and meat quality. J. of Applied Poult. Research, 22: 251-259.

Buyse, J.; P.C.M. Simons; F.M.G. Boshouwers and E. Decuypere (1996). Effect of intermittent lighting, light intensity and source on the performance and welfare of broilers. World's Poult. Sci., 52: 121130.

Calvet, S.; H. Van den Weghe; R. Kosch and F. Estelles (2009). The influence of the lighting program on broiler activity and dust production. Poult. Sci., 88: 2504-2511.

Camacho, M.A.; M.E. Suarez; J.G. Herrera; J.M. Cuca and C.M. Carcia-bojalil (2004). Effect of age of feed restriction and microelement supplementation to control ascites on production and carcass characteristics of broilers. Poult. Sci., 83:526-532.

Campo, J.L. and S.G. Da'vila (2002). Effect of photoperiod on heterophil to lymphocyte ratio and tonic immobility duration of chickens. Poult. Sci., 81: 1637-1639.

Chen, H.; R.L. Huang; H.X. Zhang; K.Q. Di; D. Pan and Y.G. Hou (2007). Effects of photoperiod on ovaria n morphology and carcass traits at sexual maturity in pullets. Poult. Sci., 86: 917-20. 
Chris, B.; A.O. Ndome Ekwu and A. Alfred (2011). Effect of feeding frequency on feed consumption, growth and feed conversion of Clarias gariepinus x Heterobranchus longifilis Hybrids. AmericanEurasian J. of Scientific Research, 6: 06-12.

Classen, H.L.; C.B. Annett; K.V. Schwean-Lardner; R. Gonda and D. Derow (2004). The effects of lighting programmes with twelve hours of darkness per day provided in one, six or twelve hour intervals on the productivity and health of broiler chickens. Br. Poult. Sci., 45: S31-32.

Demir, E.; S.Sarica; A.Sekeroglu; M.A.Ozcan and Y. Seker (2004). Effects of early and late feed restriction or feed withdrawal on growth performance, and blood constituents of broiler chickens. Acta Agri. Scandinavica, 54: 152-158.

Downs, K.M.; R.J. Lien; J.B. Hess; S.F. Bilgili and W.A. Dozier (2006). The effects of photoperiod length, light intensity, and feed energy on growth responses and meat yield of broilers. Applied Poult. Res J., 15: 406-416.

Duncan, D.B. (1955). Multiple ranges and multiple F-test. Biometrics, 11: 1042.

Duve L.R.; S. Steenfeldta; K. Thodberga and B.L. Nielsenb (2011). Splitting the scotoperiod: effects on feeding behaviour, intestinal fill and digestive transit time in broiler chickens. Br. Poult. Sci., 52:110.

El-Badry, A.S.O.; M.H. Mahrousa; Kh.A.A. Ali and W.A.H. Ali (2009). Effect of light regimes on some physiological and reproductive characteristics in Muscovy drakes. Egypt. Poult. Sci., 29:589-608.

El-fiky, A.; M. Soltan; F.H. Abdou; S. EL- Samr and B. El- Neney (2008). Effect of light regime and feeding frequency on some productive, physiological traits and hormonal profiles in broiler chicks. Egypt. Poult. Sci., 28:711-743.

El-Slamoney, A.E.; A. M.El- Neney Battaa; S.F. Hassaan; E. Raga Abd El-Karim and E.A. Abdulla (2010). Effect of photoperiod and tryptophan amino acid supplementation on pineal gland hormone (melatonin) and its relation to performance in local strain.1- Effect on laying hen performance. Egypt. Poult. Sci., 30: 927-960.

Farghly, M.F.A. (2014). Improvement of productive and reproductive performance of Dandarawi chicken through flash light program. Egypt. J. Anim. Prod., 51:129-144.

Farghly, M.F.A. and H.H.M. Hassanien, (2012). Effect of feed frequencies and durations on performance of broiler chicks. Egypt. Poult. Sci., 32:273-288.

Gharib, H.B.A.; A.A. Desoky; M.A. El-Menawey (2008). The role of photoperiod and melatonin on alleviation of the negative impact of heat stress on broilers. International J. of Poult. Sci., 7:749-756.

Gonzales, E.; J. Buyse; M.M. Loddi; T.S. Takita; N. Buys and E.Decuypere (1998). Performance, incidence of metabolic disturbances and endocrine variables of food-restricted male broiler chickens. Br. Poult. Sci., 39:671-678.

Khalil M., Hanaa; R.E. Rizk; El-Sahn A., Amany; Mahmoud A., Mona, and E.H.A. Shahein (2007). Study on the optimum light requirements on productive and reproductive performance of local chicken strain 1. Increasing lighting system effects on specific body structure measurements for local Bandarah males strain. Egypt. Poult. Sci., 27:1099-1112.

Hassanein, H.H.M.; Z.S.H. Esmail and A.A. Abdel-wareth (2011). Effects of fasting period and enzyme supplementation on performance and some physiological responses of broiler chickens. Egyptian Poultry Science, 31:453-464.

Hester, P.Y.; D.A. Wilson; P. Settar; J.A. Arango and N.P. O'Sullivan (2011). Effect of lighting programs during the pullet phase on skeletal integrity of egg-laying strains of chickens. Poult. Sci., 90: $1645-1651$.

Hoption, C.S.A. (2006). Hypothesis: Dietary iodine intake in the etiology of cardiovascular disease. J. Am. Coll. Nutr., 25: 1-11.

Ingram, D.R. and L.F. Hatten (2000). Effects of light restriction on broiler performance and specific body structure measurements. J. Appl. Poult. Res., 9: 501-504.

Khetani, T.L.; T.T. Nkukwana; M. Chimonyo and V. Muchenje (2008). Effect of quantitative feed restriction on broiler performance. Tropical Anim. Health and Prod., 41: 379-384. 
Lewis, P.D.; R. Danisman and R.M. Gous (2010). Photoperiods for broiler breeder females during the laying period. Poult. Sci., 89: 108-114.

Lewis, P.D; R. Danisman and R.M. Gous (2009a). Photoperiodic responses of broilers. III. Tibial breaking strength and ash content. Br. Poult. Sci., 50: 673-679.

Lewis, P.D; R. Danisman and R.M. Gous (2009b). Photoperiodic responses of broilers. I. Growth, feeding behaviour, breast meat yield, and testicular growth. Br. Poult. Sci., 50: 657-666.

Li, Wen-bin; Guo Yan-Li Chen; Ji-Ian Wang; Rong He; Yao Su and Dong-ge (2010). Influence of lighting schedule and nutrient density in broiler chickens: effect on growth performance, carcass traits and meat quality. Asian - Australasian Association of Anim. Prod. Societies.

Lien, R.J.; L.B. Hooie and J.B. Hess (2009). Influence of long-bright and increasing-dim photoperiods on live and processing performance of two broiler strains. Poult. Sci., 88: 896-903.

Lippens, M.; G.Room; G. DE Groote and E. Decuypere (2000). Early and temporary quantitative food restriction of broiler chickens. 1. Effects on performance characteristics, mortality and meat quality. Br. Poult. Sci., 41: 343-354.

Mahmud, S.; A. Rafiullah and I. Ali (2011). Effect of different light regimens on performance of broilers. The J. of Anim. \& Plant Sci., 21: 104-106.

Makled, M.N.; H.A.F. Mahmoud; M. EL-Sagheer and Masoud A., Marwa (2012). Effect of diurnal discontinuous feeding of optimal and suboptimal levels of lysine and/or methionine on broilers performance. Proceedings of 3rd Mediteranian Poultry Summit and 6th International Poultry Conference, 26-29 March, 2012, Alexandraia, Egypt.

Mench, J.A. (2002). Broiler breeders: Feed restriction and welfare. World's . Poult. Sci., J., 58:20-29.

Moradi, S.; M. Zaghari ; M. Shivazad; R. Osfoori and M. Mardi (2012). The effect of increasing feeding frequency on performance, plasma hormones and metabolites, and hepatic lipid metabolism of broiler breeder hens. . Poult. Sci., 92:1227-1237.

Mustafa, Y.S. and M.A. Muneer (2013). Influence of light on the hematology, lymphoid organs and production of the broilers. Sarhad. J. Agric. 29: 579-584.

National Research Council (NRC), (1994). Nutrient Requirements of Poultry.9th rev. ed. National Academy Press, Washington, D.C.

Nematallah, G.M.A.; Faten A.A.I. and A.M. Elkaity (2003). The influence of early food restriction on performance, immune-responsiveness and some physiological variables in Muscovy ducklings. Egypt. . Poult. Sci., 23: 355-373.

Nielsen, B.L.; M. Lither and F. Noddegaard (2003). Effect of qualitative and quantitative feed restriction on the activity of broiler chickens. Applied Anim. Behavior Sci., 83:309-323.

Novel, D.J.; J.W. Ng'ambi; D.Norris and C.A. Mbajiorgu (2009). Effect of different feed restriction regimes during the starter stage on productivity and carcass characteristics of male and female Ross 308 broiler chickens. Inter. J. of Poult. Sci., 8: 35-39.

Ohtani, S. and S. Leeson (2004). The Effect of Intermittent Lighting on Metabolizable Energy Intake and Heat Production of Male Broilers. Poult. Sci., 79:167-171.

Onbaşılar, E.E.; H. Erol1; Z. Cantekin and Ü. Kaya (2007). Influence of intermittent lighting on broiler performance, incidence of tibial dyschondroplasia, tonic immobility, some blood parameters and antibody production. Asian-Aust. J. Anim. Sci., 20: 550-555

Onbasilar, E.E.; S. Yalcin; E. Torlak and P. Ozdemir (2009). Effects of early feed restriction on live performance, carcass characteristics, meat and liver composition, some blood parameters, heterophil-lymphocyte ratio, antibody production and tonic immobility duration. Tropical Anim. Health and Prod., 41: 1513-1519.

Oyedeji, J.O. and J.O. Atteh (2005). Response of broilers to feeding manipulations. Inter. J. of Poult. Sci., 4: 91-95.

Ozkan, S.; C. Takma; S. Yahav; B. Soğut; L. Turkmut; H. Erturun and A. Cahaner (2010). The effects of feed restriction and ambient temperature on growth and ascites mortality of broilers reared at high altitude. Poult. Sci., 89:974-985. 
Ozkan, S.; I. Plavnik and S. Yahav (2006). Effects of early feed restriction on performance and ascites development in broiler chickens subsequently raised at low ambient temperature. J. of Applied Poult. Research, 15:9-19

Petek, M. (2000). The effect of feed withdrawal during the day on some production traits and blood parameters of broilers. Turkish J. of Veterinary and Anim. Sci., 24: 447-452

Peter, R.F. and A.G. Gernat (2006). Factors that affect feed intake of meat birds: a review. Inter. J. of Poult. Sci., 5: 905-911.

Rahimi, G.; M. Rezaei; H. Hafezian and H. Saiyahzadeh (2005). The effect of intermittent lighting schedule on broiler performance. Inter. J. of Poult. Sci., 4: 396-398.

Rajman, M.; M. Jurani; D. Lamosova; M. Macajova; M. Sedlackova; L. Kostal; D. Jezova and P. Vyboh (2006). The effects of feed restriction on plasma biochemistry in growing meat type chickens (Gallus gallus). Comparative Biochemistry and Physiology, Part A: 145:363-371.

Renden, J.A.; E.T. Moran and S.A. Kincaid (1996). Lighting programs for broilers that reduce leg problems without loss of performance or yield. Poult. Sci., 75: 1345-1350.

Saiful, I.M.; M. Fujita and T. Ito (2002). Effect of physical activity on heat production of white leghorn hen under different lighting regimes. J. Poult. Sci., 39: 159-166.

Saleh, E.A.; S.E. Watkins; A.L. Waldroup and P.W. Waldroup (2005). Effects of early quantitative feed restriction on live performance and carcass composition of male broiler grown for further processing. J. of Applied Poult. Research, 14: 87-93.

Sanotra, C.S.; J. Damkjer Lund and K.S. Vestergaard (2002). Influence of Light-Dark schedules and stocking density on behaviour, risk of leg problems and occurrence of chronic fear in broilers. $\mathrm{Br}$. Poult. Sci., 43: 344-354.

SAS (1996). SAS User's Guide, Statistics (6.2th Ed.), SAS Institute Inc., Cary, NC.

Schwean-Lardner, K.; B.I. Fancher and H.L. Classen (2012). Impact of daylength on the productivity of two commercial broiler strains. Br. Poult. Sci., 53: 7-18.

Schwean-Lardner, K.; B.I. Fancher; S. Gomis; A. Van Kessel; S. Dalal and H.L. Classen (2013). Effect of day length on cause of mortality, leg health, and ocular health in broilers. Poult. Sci., 92:1-11.

Shutze, J.V.; L.S. Jansen; J.S. Carver and W.F. Matson (1996). Influence of various lighting regimes on the performance of growing chickens. Washington Agric. Expt. Sta. Tech. Bull., 36: www.reproduction-online.org.cgi/reprint/7/3/409.

Soliman, M.M.; B.A. El-Neney; M.A. Kalamah and A.K. Alm El-Dein (2006). Improving productive and physiological parameters of broilers using some light regimes and feed additives. Egypt. J. Animal Production, the 13th Conference of the Egypt. Society of Anim. Prod., Cairo, Egypt.10-11 Dec, 269-286.

Svihusa, B.; V.B Lunda; B.Borjgena; M.R. Bedfordb and M. Bakkenac (2013). Effect of intermittent feeding, structural components and phytase on performance and behaviour of broiler chickens. Br. Poult. Sci., 54: 222-230.

Tolkamp, B.; J.V. Sandilands and A. Kyriazakis (2005). Effects of qualitative feed restriction during rearing on the performance of broiler breeders during rearing and lay. Poult. Sci., 84:1286-1293.

Urdaneta-rincon, M. and S. Leeson (2002). Quantitative and qualitative feed restriction on growth characteristics of male broiler chickens. Poult. Sci., 81:679-688.

Velleman, S.G.; C.S. Coy and D.A. Emmerson (2014). Effect of the timing of posthatch feed restrictions on the deposition of fat during broiler breast muscle development. Poult. Sci., 93: 2622-2627.

Weeks, C.A.; T.D. Danbury; H.C. Davies; P. Hunt and S.C. Kestin (2000). The behavior of broiler chickens and its modification by lameness. Appl. Anim. Behav. Sci., 67: 111-125.

Zeman, M.; P. Pavlik; D. Lamosova; I. Herichova and E. Gwinner (2004). Development of circadian hythmicity: entrainment of rhythmic melatonin production by light and temperature in the chick embryo. Avian and Poult. Biology reviews, 15: 197-204.

Zhan, X.A.; M. Wang; H. Ren; R.Q. Zhao; J.X. Li and Z.L. Tan (2007). Effect of early feed restriction on metabolic programming and compensatory growth in broiler chickens. Poult. Sci., 86:654-660. 


\title{
Farghly and Makled
}

Zubair, A.K. and S. Leeson (1996). Compensatory growth in the broiler chicken: a review. World's Poult. Sci., J. 52: 189-201.

تطبيق نظم التغذية و إضاءة الوميض المتقطعة في رعاية كتاكيت التسمين

\author{
محمد فرغلى علم الدين فرغلى و محمد نبيل مقلد \\ قسم إنتاج اللدواجن ـ كلية الززراعة - جامعة أسيوط ـ أسيوط ـ مصر.
}

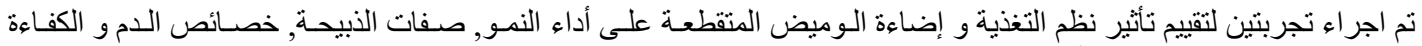

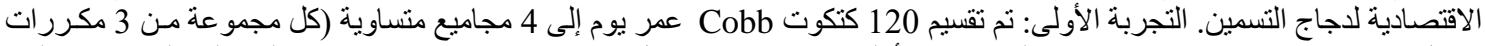

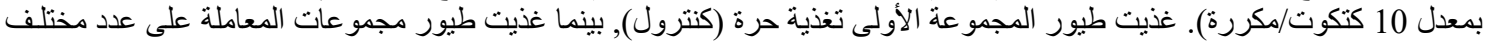

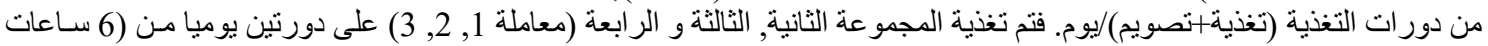

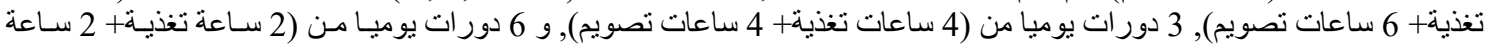

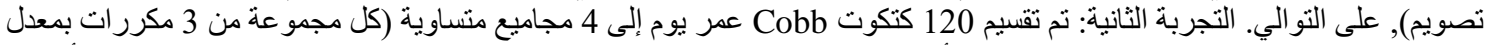

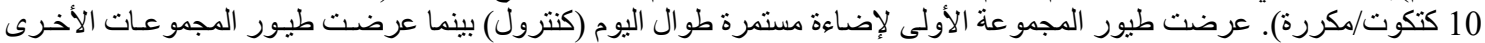

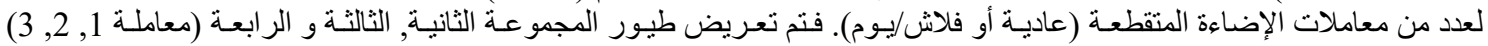

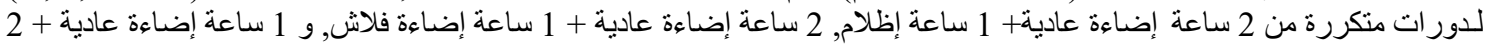

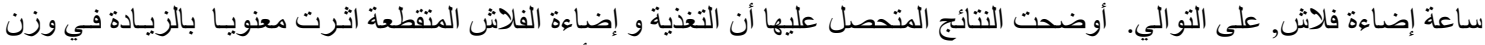

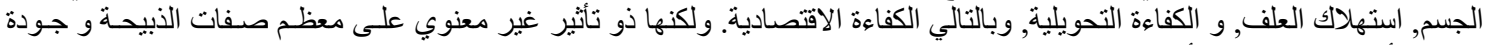

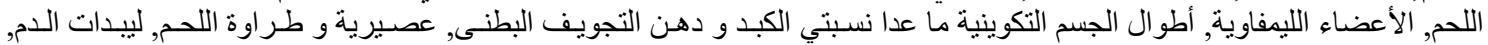

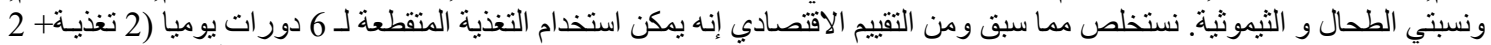

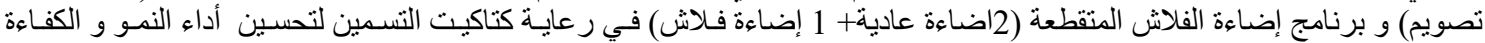

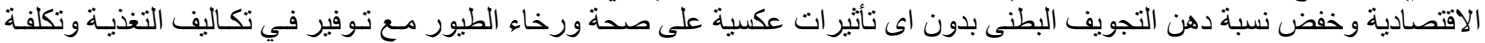
الطاقة الكهربائية للإضاءة المستمرة. 